\title{
Elites and Institutional Persistence
}

\author{
James A. Robinson*
}

July 2010

\begin{abstract}
Particular sets of institutions, once they become established in a society, have a strong tendency to persist. In this paper I argue that understanding how elites form and reproduce is key to understanding the persistence of institutions over time. I illustrate this idea with a simple political economy theory of institutions and through examples from Liberia, the US, South Africa and Germany I show how elites influence institutions. To change institutions requires having an understanding of how reforms influence the preferences, capabilities and strategies of elites.
\end{abstract}

Keywords: elites, political economy, persistence of institutions

JEL classification: D02, D72, N40, O43

Copyright (C) UNU-WIDER 2010

* Harvard University, USA, E-mail: jrobinson@gov.harvard.edu

This study has been prepared within the UNU-WIDER project on The Role of Elites in Economic Development, directed by Alice Amsden, James Robinson, and Alisa DiCaprio.

UNU-WIDER gratefully acknowledges the financial contributions to the research programme by the governments of Denmark (Royal Ministry of Foreign Affairs), Finland (Ministry for Foreign Affairs), Sweden (Swedish International Development Cooperation Agency-Sida) and the United Kingdom (Department for International Development-DFID). 


\section{Acknowledgements}

The World Institute for Development Economics Research (WIDER) was established by the United Nations University (UNU) as its first research and training centre and started work in Helsinki, Finland in 1985. The Institute undertakes applied research and policy analysis on structural changes affecting the developing and transitional economies, provides a forum for the advocacy of policies leading to robust, equitable and environmentally sustainable growth, and promotes capacity strengthening and training in the field of economic and social policy making. Work is carried out by staff researchers and visiting scholars in Helsinki and through networks of collaborating scholars and institutions around the world.

www.wider.unu.edu publications@wider.unu.edu

UNU World Institute for Development Economics Research (UNU-WIDER)

Katajanokanlaituri 6 B, 00160 Helsinki, Finland

Typescript prepared by the Author.

The views expressed in this publication are those of the author(s). Publication does not imply endorsement by the Institute or the United Nations University, nor by the programme/project sponsors, of any of the views expressed. 


\section{Introduction}

There is a great deal of consensus amongst social scientists that the main explanation for comparative economic performance is variation in economic institutions, construed broadly enough to include economic policies. This consensus reaches from economics (North and Thomas, 1973, North, 1990, Acemoglu, Johnson and Robinson, 2001, 2002), though sociology (Evans, 1995) to political science (Amsden, 1989, Haggard, 1990, Wade, 1990). Prosperous countries have economic institutions and policies which create the incentives necessary for sustained factor accumulation and technical change. These involve the protection of property rights and a whole gamut of institutions which make markets work and create a level playing field so that those with ideas and talent can exploit them. They also involve government policies which provide public goods and key inputs which stimulate market activities. Poor countries lack such institutions.

The acceptance of the role of comparative institutions in development leads to many important questions, perhaps the most fundamental of which is why do institutions differ? To answer this question one needs a theory of institutions. The most natural approach is to treat institutions as an endogenous political choice of society which differs in different societies because of differences in political institutions and the distribution of political power which map preferences over institutions into institutional outcomes - something I will call the "political equilibrium'. When it comes to explaining why the political equilibria of societies vary, most scholars take a deeply historical approach. For instance, Acemoglu, Johnson and Robinson's (2001, 2002) empirical approach was based on exploiting the experience of European colonialism as a source of variation in institutions. They argued that significant institutional variation in the colonial world was caused by differences in the circumstances found by colonizing powers in different parts of the world. Here political institutions and the distribution of power are simple, the colonial powers dominated and created the institutions that suited them best. Some of these sets of institutions were consistent with long-run growth, others were not. Evans (1995) instead argued that the historical legacy of state institutions and bureaucracy had a key impact on the choice and success of industrialization strategies. In his theory East Asian 
countries were able to industrialize because they benefitted from the legacy of bureaucracy which had historically evolved to rule China.

All such historical arguments build in a lot of institution persistence. Indeed the theory of institutional variation which emerges from this work is premised on the observation that institutions tend to be highly inertial. Once a set of institutions comes to dominate society it tends to persist for long periods of time though the institutional path can certainly change in the context of major 'critical junctures'. These could include factors external to a society such the imposition of colonial rule, inter-state war, or globalization, but they also include changes endogenous to society such as revolution, or industrialization and the rise of the middle class.

From this perspective to ask why a society has the institutions that it does one has to look at its history to see what forces have buffeted it and the impact they have had and how a society has or has not changed during particular critical junctures. Countries have different institutions because they have different histories, though obviously there may be forces for institutional convergence and societies which were affected by common shocks and forces may well have similar institutions. This is true in much of Latin America, for example, which experienced relatively similar patterns of colonial rule, or in West Africa where the slave trade had similar effects on institutions in many countries. They may also respond in similar ways at subsequent critical junctures. For instance, the impact of globalization in Latin America in the late 19th century with the great economic opportunities it presented generally led to a deterioration in economic institutions such as property rights and political institutions as it fostered the consolidation of more autocratic regimes in countries like Guatemala and Mexico. Similarly in West Africa, the abolition of the slave trade and the inauguration of 'legitimate commerce' led to similar responses all along the coast from Asante to Dahomey. The response of societies to shocks was filtered through the existing political equilibrium in much the same way as Postan (1944) had previously analyzed the institutional implications of commercial expansion in late medieval Europe (see also Brenner, 1976). This is to say that there is a large amount of path dependence in the institutions of a society.

But these ambitious claims about institutional persistence also generate puzzles. For in- 
stance, one of the most famous system of forced labor in colonial Latin America was the mining Mita of Peru. Dell (2007) has shown that compared to places outside the catchment area of the Mita, those in the Mita area have 1/3 lower household consumption today. These areas also have fewer public goods, particularly roads and until recently education, and farmers tend to be much more involved in subsistence production. But despite these empirical links between the past and today and even if the Peruvian Mita lasted around 250 years, it was abolished 200 years ago. What is the mechanism via which its effects persist today?

In this chapter I argue that a crucial factor in explaining the persistence of institutions is how elites form around sets of institutions and how elites persist and reproduce over time. By an elite I simply mean a distinct group within a society which enjoys privileged status and exercises decisive control over the organization of that society (though this will be a matter of degree in reality). In some situations it is much easier to identify who the elite was or is. In colonial Peru, for instance, we can plausibly argue that the elite consisted of Spanish settlers, the colonial state bureaucracy (often manned by non-settlers or peninsulares) and indigenous elites who cooperated with and were co-opted by the colonial state. My argument also implies that a key factor in institutional change will be what happens to the elite. Change can be triggered by disunity of elites or elite decay, though it can also be triggered by changes in elite preferences.

To see how this might work, let's return to Dell's analysis of the Mita. She shows that the way this particular institution influenced long-run economic outcomes, even after it had been abolished, was precisely because of the impact it had on elites and elite interests. During the colonial period Spanish settlers were only able to form large landholdings outside the Mita areas because the colonial state wanted to stop them competing for the mining labor. After independence when the Mita was abolished, it was these settler elites who ran the country. In consequence they were able to influence the construction of infrastructure and allocation of public goods, which went to areas where they owned land, outside the Mita zone. In the case of the Mita the colonial institution has had persistent long-run effects because of the way it influenced the spatial distribution of the elite and its investments and interests. This elite 
persisted over time and that is why the impact of the Mita also persists.

In the Peruvian case, and in Latin America more generally, there has been a lot of well documented persistency of elite families and identities. ${ }^{1}$ Yet a theory of institutional persistence based on the persistence of families and dynasties can only be a part of what is required to explain the world. To see why consider the many claims made about the persistence between colonial institutions and the post-independence development patterns in Sub-Saharan Africa (Young, 1994, Mamdani, 1996, Cooper, 2002). In these cases a colonial elite was replaced by a largely new and different elite, so the mechanisms via which the Mita persisted do not seem to be relevant to these cases. But this 'circulation of elites' does not imply that elites are not relevant for institutional persistence. This is because the preferences and behavior of elites are highly path dependent, a phenomenon reminiscent of what Michels (1915) called the 'iron law of oligarchy' (related ideas are due to Mosca, 1939, and Pareto, 1968). Michels observed that (1915, pp. 353-354).

"society cannot exist without a "dominant" or "political" class, and that the ruling class, while its elements are subject to frequent partial renewal, nevertheless constitutes the only factor of sufficiently durable efficacy in the history of human development. [T] he government, or, .. the state, cannot be anything other than the organization of a minority. It is the aim of this minority to impose upon the rest of society a "legal order" which is the outcome of the exigencies of dominion and of the exploitation of the mass ... Even when the discontent of the masses culminates in a successful attempt to deprive the bourgeoisie of power, this is ... effected only in appearance; always and necessarily there springs from the masses a new organized minority which raises itself to the rank of a governing class."

Michels observation was that society is always governed by an elite who organize things for their own benefit and that a new elite could replace an old one with little real change. It is natural to extend this argument to include the idea that how a new elites does things depends

\footnotetext{
${ }^{1}$ This is particularly well documented in Central America, see Stone (1990) and Paige (1997) in general and Casaús Arzú (2007) for Guatemala.
} 
on how the old elite did things (Acemoglu and Robinson, 2007). Thus even in cases like SubSaharan Africa where elite identities changed after independence, the way they behaved was heavily contingent on the institutional environment they inherited and the way that colonial elites had behaved. Thus elites are again crucial to explaining institutional persistence.

The chapter proceeds as follows. In the next section I sketch the simple political economy approach to institutions which unlerpins my approach. In this context I give a specific example of an elite, the Americo-Liberians of Liberia. Section 3 then discussed institutional persistence and the key role of elites in institutional persistence using examples from the history of the US South and South Africa. Section 4 applies this approach to institutional change, again arguing for a key role for elites. I here return to the US South and contrast the role of the elite in institutional change there with what happened in Europe during the French Revolution. Section 5 concludes.

\section{Elements of a Theory of Institutions}

I now briefly discuss a theory of institutions (see Acemoglu, Johnson and Robinson, 2005, and Acemoglu and Robinson, 2011). Economic institutions matter for economic growth because they shape the incentives of key economic actors in society, in particular, they influence investments in physical and human capital and technology, and the organization of production. Economic institutions not only determine the aggregate economic growth potential of the economy, but also the distribution of resources in the future. In other words, they influence not only the size of aggregate income, but how income is divided among different groups and individuals in society. ${ }^{2}$

Economic institutions and policies are endogenous and are determined as collective choices of the society. Clearly, there is no guarantee that all individuals and groups will prefer the same set of economic institutions because, as noted above, different economic institutions lead to different income distributions. Consequently, there will be a conflict of interest over the

\footnotetext{
${ }^{2}$ As I noted in the introduction include economic policies along with economic institutions. Like institutions, policies are chosen by those with political power and they have large impacts on the incentive structure of society so for the purposes of the discussion it is not important to distinguish between them.
} 
choice of economic institutions. In such a situation it will be the distribution of political power in society that determines what institution are chosen. The group with more political power will tend to secure the set of economic institutions that it prefers.

The distribution of political power in society is also endogenous, however. Following Acemoglu and Robinson (2006) I distinguish between two components of political power: de jure (institutional) and de facto political power. Here de jure political power refers to all types of power that originates from the political institutions in society. Political institutions determine the constraints on and the incentives of key actors in the political sphere. Examples of political institutions include the form of government, for example, democracy vs. dictatorship or autocracy, and the extent of constraints on politicians and political elites. There is more to political power than political institutions, however. A group of individuals, even if they are not allocated power by political institutions, for example as specified in the constitution, may nonetheless possess political power. Namely, they can revolt, use arms, hire mercenaries, co-opt the military, or use economically costly but largely peaceful protests in order to impose their wishes on society. I refer to this type of political power as de facto political power, which itself has two sources. First, it depends on the ability of the group in question to solve its collective action problem, i.e., to ensure that people act together, even when any individual may have an incentive to free ride. Second, the de facto power of a group depends on its economic resources, which determine both their ability to use (or misuse) existing political institutions and also their option to hire and use force against different groups.

It will be composition of de facto and de jure power in society that determines the actual power of a group or set of interests and this will determine which economic institutions arise. It is obvious from this description that there are large forces here which generate persistence in the political economy equilibrium. If a certain group is empowered by the existing structure of political power then they will choose economic institutions that favor them. This will increase their wealth and be one channel through which their de facto power will persist or increase. Moreover, those who hold power today will not only be able to determine economic institutions today. They will also be able to determine political institutions in the future which tends to 
cement the de jure power of such a group. Hence the distribution of political power and thus economic institutions is naturally highly persistent over time. Nevertheless, there may be intrinsic dynamics or shocks to the system that lead to redistributions of power and thus changes in economic institutions. It may also be the case that the incentives of those in power are changed, perhaps because of technical innovation or new market opportunities, and this may change economic institutions we well.

This dynamic vision emphasizes that those with power today take decisions not just to maximize their income today, but also to maintain their grip on power. These goals are often in contradiction. This can be for the simple reason that economic policies which increase even the incomes of elites today may increase the incomes of opponents even more, thus influencing the future distribution of de facto power. It may also be that, as pointed out in the seminal study by Bates (1981), good economic policies are not good politics. In particular though providing public goods may increase the incomes of the elite, staying in power may be better achieved by using redistributive instruments which can be targeted at supporters and withheld from opponents.

Institutions therefore are chosen by those with the power to do so. In many societies this group is small and coherent enough to sensibly be called an elite. It is useful to give a very specific example of one such elite whose preferences and coherence have long determined the organization of the economy in Liberia.

\subsection{Example of an Elite: The American-Liberians}

The modern nation of Liberia was born in 1820 by the American Colonization Society (ACS) as a home for freed and repatriated African slaves. In 1847 Liberia became independent of the ACS and the year 1877 saw the emergence of the True Whig Party (TWP) which would dominate politics until the coup of Samuel Doe in 1980. The TWP party was the political vehicle for the Americo-Liberians, the decedents of the freed slaves brought back to Africa by the ACS. In the 1960s the Americo-Liberians comprised about 3-5\% of the population and completely dominated all the countries' institutions (see Fraenkel, 1964, for a picture of the 
society in the early 1960s). As Dalton (1964, p. 581) put it

"to understand Liberian politics, knowledge of kinship connections is more useful than knowledge of the Liberian constitution."

The Americo-Liberians set themselves up as an elite, ruling the indigenous Africans. They structured economic institutions to extract rents from the rest of society and political institutions to guarantee their monopoly of power. These economic institutions included slavery as late as the 1920s and even in the 1960s $1 / 4$ of the labor force was mobilized via compulsion. In most economies it is a stylized fact that wage payments represent about $2 / 3$ of national income. In Liberia the stylized facts were rather different. As a result of the severe labor repression in 1950 wages were $19.8 \%$ of national income and in 1960 they were $27.1 \%$. Moreover, as in the above discussion, the elite were not just concerned with the distribution of economic benefits, they were also concerned about the distribution of political power. As Dalton (1964, p. 581) observed

"the economic backwardness of Liberia is not attributable to the lack of resources or to domination by foreign financial or political interests. The underlying difficulty is rather that the traditional Americo-Liberian rulers, who fear losing political control to the tribal people, have not allowed those changes to take place which are necessary to develop the national society and economy."

The nature of the elite is well brought out by Figure 1 which shows how the country was run in 1960 by the family of Presidency of William V.S. Tubman who ruled from 1944 to 1971. President Tubman's brother was the Ambassador to the USA. His brother's brother in law was Ambassador to Germany. President Tubman's father was the President of the General Confederation of Labor, the main association of labor unions and his grandfather was the Vice-President of Liberia. His granduncle was the Senator of Monsanto County, which is the county where the capital Monrovia is. Another granduncle was the secretary of commerce, whose step brother was the President of the central bank. It was a family business embedded 
within the big family of the Americo-Liberians. Figure 2 shows some simple data on historical political institutions in Liberia from the Polity IV project. ${ }^{3}$ The first is the Polity score which is a commonly used measure of how democratic a country is. This score runs from 10, the most democratic, to -10, the least. I also include Polity's index of 'constraints on the executive' which runs from 7 , the most constraints, to 1 , the least. The figure forcefully illustrates the impact of the consolidation of the power of the Americo-Liberians under the TWP.

\section{$3 \quad$ Elites and Institutional Persistence}

The 'model' of the last section suggests two obvious mechanisms of institutional persistence. First, those with power today choose political institutions in the future and they naturally tend to choose those with reproduce their de jure power. Second, those with power today determine economic institutions which tend to distribute resources in their favor thus reproducing their de facto power. So once an elite has the power to determine the choice of institutions this power will tend to persist over time. This power may well be handed down to the children of the elite so that elite dynasties form, as was indeed the case in Liberia. The power of such dynastic elites to control economic institutions and thus patterns of development is very powerful and can even bridge revolution and other large shocks. Moreover, it is consistent with quite large changes in the specifics details of institutions (Acemoglu and Robinson, 2008a) because, for example, there are many ways to extract rents from labor. As an example of these issues let me consider the economic and political history of the US South.

\subsection{Persistence of Elites and Institutions in the US South ${ }^{4}$}

Before the Civil War the US South was run by plantation owners, and the economy was based on a system of slavery and labor-intensive cotton production. The South was relatively poor (about 70\% of the national level of GDP per-capita), there was little manufacturing industry, low urbanization, and a far lower density of canals and railroads than in the rest of the country, particularly the North (see Bateman and Weiss, 1981, Wright, 1986, Ransom and Sutch, 2001).

\footnotetext{
${ }^{3}$ http://www.systemicpeace.org/polity/polity4.htm

${ }^{4}$ This section is based on Acemoglu and Robinson (2008a,b).
} 
The defeat of the South in the Civil War on the surface led to major alteration in economic and political institutions. Slavery was abolished and freed male slaves given the right to vote. One might have anticipated a dramatic change in the incentive environment and economic outcomes. Instead, what emerged was a labor-intensive, low wage, low education and repressive economy that looked remarkably like the antebellum Southern economy. Economic performance got relatively worse in the South after the Civil War with GDP per-capita declining to about $50 \%$ of the national average where it stayed until the 1940s.

The reason for this is quite simple. Despite losing the Civil War, the traditional landed elites could sustain their political control of the South, particularly after Reconstruction ended in 1877 and the Union army was withdrawn. These elites were able to block economic reforms that might have undermined their power, such as the distribution of 50 acres and a mule to each freed slave, and they were able to use their local political power to disenfranchise blacks and re-exert control over the labor force. They did this through the use of Black Codes, Vagrancy Laws, Ku Klux Klan and Jim Crow (Woodward, 1955). Table 1 vividly shows the persistence of the landed southern elites in four 'black belt' counties of Alabama. This was an area at the heart of the cotton economy. The table, from Wiener, 1978, uses micro data from the US census to identify the 25 largest landowners in 1870 in these four counties in terms of land values. The other columns then show which of these 25 were amongst the largest 25 landowners in 1860 and 1850. One sees that there is amazing persistence in the identity of these big landowners which is only slightly disrupted by the Civil War.

In the US South even though political institutions changed in such a way as to redistribute de jure political power away from the white elites, the elite was still very cohesive as a group. As a consequence they were able to compensate for the change in political institutions through the use of de facto power. It is perhaps not surprising that the plantation elites had such a relative advantage over the newly freed slaves in terms of their ability to act collectively. In consequence they maintained their political control (see Wiener, 1978, for a fascinating study of this). Though political control no longer allowed slavery to be used, there were many other ways that the cotton planters could extract rents and repress the labor force. For economic 
performance however, there was little difference in which sorts of method of labor repression was used. The economy did not improve because the incentive environment for the mass of the population persisted.

Thus to understand the long-run relative economic backwardness of the US South and how this persisted after the Civil War it is crucial to examine the role and power and persistence of the Southern landed elite.

\subsection{Circulation of Elites and Institutional Persistence in South Africa}

As I observed in the introduction, there are clear examples where old elites are replaced by new ones, but where one also sees continuity in economic institutions. I argued there that a potential explanation for such a phenomenon is that the strategies of elites are path dependent. The fact that an incumbent elite organized economic institutions in a particular way makes this relatively attractive for a new elite to do the same. It may also be the case that not all elements of the elite change. In many former British Sub-Saharan African colonies, for example, 'traditional rulers' who had been heavily used by the British to rule the colonies indirectly, maintained their power and positions after independence, creating a large element of direct elite persistence. In other cases, such as South Africa, the transition from Apartheid and white rule to democracy in 1994 led to the destruction of the white political elite, but left a large amount of the white economic elite in place.

The South African case is an interesting one to consider the ramifications of elite circulation for institutional persistence. After the election of the African National Congress (ANC) in 1994 one would have anticipated large changes from this redistribution of political power towards the black majority. This event did lead to the abolition of the last few apartheid laws (others, such as the Colour Bar had already been abolished in the 1980s) and clear change in the power relations between elites. What else might happen could have been predicted by the historical commitments of the ANC at least since the formulation of the Freedom Charter in 1955 which stated

"The national wealth of our country, the heritage of South Africans, shall be re- 
stored to the people; The mineral wealth beneath the soil, the Banks and monopoly industry shall be transferred to the ownership of the people as a whole; All other industry and trade shall be controlled to assist the wellbeing of the people;" 5

Such a goal was also confirmed by Nelson Mandela after his release from prison and during his first public address to South African big business in May 1990

"it is quite obvious that the economic power relations represented by the excessive concentration of power in a few white hands have to change ... one of South Africa's imperatives is to end white domination in all its forms, to deracialise the exercise of economic power".

But a prediction based on such statements would have been a bad one. In fact the ANC quickly abandoned the radical economic policies which it had advocated while opposing Apartheid and adopted prudent market friendly ones instead. Since 1994 while GDP per-capita has grown, income inequality has risen substantially, there has been practically no redistribution of assets to offset the huge heritage of exploitation and expropriation by whites. Average real wages have actually fallen. This has happened even though South Africa was probably already the most unequal country in the world. These outcomes are not what you might have expected given the history of the country, but they are what Robert Michels might have expected.

In 1993, just before the end of white rule, the financial services company Sanlam, a pillar of the Apartheid economy, sold $10 \%$ of its stake in Metropolitan life to a black owned consortium led by Nthato Motlana a former secretary of the ANC's Youth League and one-time doctor to Nelson Mandela and Bishop Desmond Tutu. Since then white firms have systematically formed links with prominent ANC politicians and their spouses/relatives, putting them on the boards of directors and selling discounted shares to consortia formed by then. This process has been called Black Economic Empowerment (BEE). Though initially this process was obviously aimed at securing property rights for whites by giving the ANC elite a stake in capitalism, it

\footnotetext{
${ }^{5}$ http://www.anc.org.za/ancdocs/history/charter.html
} 
clearly has also created a vested interest for this new elite in a highly concentrated industrial structure and existing entry barriers and rents. Moreover, many specific aspects of Apartheid still remain, such as the spatial distribution of the population. Though part of Black Economic Empowerment is being used as an instrument of affirmative action to promote the economic interests of black South Africans more broadly, the first-order effect has been to greatly enrich the politically powerful new elite. A simple illustration of this comes from Table 2, which reproduces the CV of Max Sisulu a prominent ANC politician and son of Walter Sisulu, one of the historic figures of the party. This shows that not only has Sisulu been an ANC member of Parliament but is also a member of the ANC's executive committee, the party's governing body. The last section shows the extraordinary number of directorships that Sisulu has, including many where he is a non-executive director. This is what a lot of Black Economic Empowerment means in practice, large companies giving sinecures to politically important people so that the pre-existing economic institutions persist.

Figure 3 gives some sense of the scale of this phenomenon. In it I mapped the connections between important ANC politicians (members of the national and state legislatures and members of the executive committee since 1994) and companies by looking at their boards of directors. Sisulu is halfway up the right-hand side. Most prominent are such figures as Cyril Ramaphosa, the former leader of the miner's union who was the chief negotiation for the ANC in the bargaining which led to the end of Apartheid. Also prominent is Tokyo Sexwale, like Nelson Mandela a former inmate of Robben Island prison during the Apartheid era.

Though there are different ways to interpret this phenomenon, a plausible one is that it is an example of the iron law of oligarchy in action. Though the changes in political institutions that took place in 1994 significantly redistributed de jure political power in South Africa, it did not necessarily lead to large changes in economic institutions. This was for several reasons. First, the previous set of institutions generated huge rents for the white elite, it can do the same for a new, mostly black, elite. Second, the old elite was heterogeneous and the white economic elite still hangs on and has a great deal of de facto power to try to influence the nature of economic institutions in post-Apartheid South Africa. 


\section{Elites and Institutional Change}

The two examples of the last section were designed to show that even in what appears to be institutional change, there can be persistence and that to understand this persistence one needs to think about the role of elites. But we also observe important transitions in institutions toward political equilibria that lead to better economic performance and higher welfare. Institutional change will arise if there is a real change in the political equilibrium - in the distribution of power in society, for example towards those with a vested interest in socially more desirable institutions. Change can also happen when the parameters of the system alter in a way which leads the interests of the elites who control power to change. I call this 're-orienting elites'. Change can also occur when there is a big enough change that the iron law of oligarchy is broken. I shall refer to this as 'breaking elites'.

I illustrate these ideas by returning first to the US South where both mechanisms are in play. I then focus on the breaking elites mechanism in the era of the French Revolution.

\subsection{Re-orienting Elites: The Emergence of Good Institutions in the US South $^{6}$}

Starting in the 1940s rapid change began to take place in the political equilibrium of the US South. This went along with institutional change. This took place in the context of several momentous changes. For one the isolation of the southern labor market ended in the context of mass emigration (Wright, 1999). There were large changes in technology, particularly the mechanization of cotton picking after 1950 (Heinicke, 1994). There was the final collapse of institutionalized racial discrimination in labor markets and social life and re-enfranchisement of Blacks culminating in the Voting Rights Act of 1965 (Besley, Persson and Sturm, 2010). The consequence of these changes was that southern economy converged to the US average.

These changes were driven by a number of interacting forces which both changed the ability of Southern elites to maintain the previous system and also their incentives to do so. The ability of whites to continue with the institutions which had been in effect since the

\footnotetext{
${ }^{6}$ This section is based on Acemoglu and Robinson (2008a,b).
} 
late 19th century was severely undermined by the fact that blacks in South finally solved the collective action problem (McAdam, 1983). The civil rights movement made much of the previous system unenforceable. Black collective action was facilitated by the intervention of the federal government. At the same time there was a much smaller ability and incentive for the whites to continue to repress labor. The huge migration of blacks out of the South could no longer be controlled. At the same time technological change, particularly the mechanization of cotton picking made it far less important to repress labor. Thus the preferences of the white elite changed while at the same time their power diminished.

There was real change therefore in the political equilibrium in the South which led to much better economic institutions. The old economy based on extracting rents from the blacks crumbled, along with all the negative externalities that it had for other parts of the economy. No new elite arose to carry on repressing black labor using different instruments and the situation did not turn on its' head with blacks extracting rents from whites. This may have been because of the technological changes that took place at the same time, but more likely it was because the South is embedded in a larger economy with well functioning institutions. This latter feature of the South may have considerable raised the opportunity cost of having bad economic institutions.

\subsection{Breaking Elites: The Economic Effects of the French Revolution}

In the US South the elite was not overthrown. But as we saw above, this is neither necessary nor sufficient for institutional change to take place. Sometimes, however, the overthrow of an elite does lead to sufficient changes in institutions that when a new elite forms it does so with different specific investment and interests. It may also be that this new elite assumes power with these different interests. In this case the breaking of elites can come with real institutional change.

An important example of this phenomenon occurred during the period of the French Revolution (Acemoglu, Cantoni, Johnson and Robinson, 2009). After 1792 French armies invaded large parts of Western and Southern Europe and when they did so they implemented many 
of the institutional reforms which had been innovated in France after the Revolution. These reforms included the creation of republican constitutions, abolition of feudalism and introduction of equality before the law, abolition of guilds, introduction of the civil code. For example in the Rhineland, even though some scholar emphasize that there was a fair amount of plunder and resulting resentment by the local population (e.g., Blanning, 1983) the importance of the revolutionary reforms appears undeniable. In 1798 the seigneurial regime and the guilds were abolished (Blanning, 1983, pp. 137 and 155), and this paved the way to a relatively free labor market. There were also significant legal changes with a commercial court in Aachen in 1794, and followed with similar courts elsewhere in the Rhineland (Diefendorf, 1980, pp. 159-160), which were to play an important role in the creation of commercial and industrial businesses in the years to follow. Subsequently the civil code (Code Napoléon) was implemented. Kisch emphasizes the economic importance of this (1989, p. 212):

"When the many strands of commercial legislation were subsequently consolidated in the Code Napoléon, the Rhineland (on the left bank) was not only given a most up-to-date legal framework, but also a system of government in close harmony with the needs of a buoyantly industrializing society."

Instead of the traditional elite by 1810 merchants/manufacturers comprised about half the members of Conseil General (municipal administrations) in leading Rhineland towns (Diefendorf, 1980, p. 115), and businesspeople were also well represented in the higher department-level Conseil General.

Reforms were also systematically introduced into other parts of Germany which were made into satellite kingdoms by Napoleon. For example, Connelly (1965, p. 184) notes that in the constitution of Westphalia, which was issued at Fontainebleau on November 15, 1807,

"the king's subjects were guaranteed equality before the law and religious liberty; serfdom and feudal rights were abolished; noble titles were affirmed, but were to command no special rights, privileges or offices. Taxes were to fall equally on all classes in all parts of the kingdom." 
Acemoglu, Cantoni, Johnson and Robinson (2009) show that parts of Europe which were reformed by the French between 1792 and 1815 experienced significantly more rapid economic growth and increases in urbanization in the 19th century compared to those parts which were not reformed. This is also true just comparing the parts of Germany that were reformed to those that were not.

A crucial part of the mechanism which appears to generate these findings is the impact of French invasion and the 1815 Congress of Vienna on elites. After the final collapse of Napoleon's Empire the institutional reforms implemented over the previous 25 years suffered various fates. Within Germany, to a first approximation, the reforms were most clearly persistent in places where the old elites did not return. In Germany these were the areas of Napoleonic Germany that were ceded to Prussia at the Congress of Vienna. The presence of a new elite created by the reforms and determined to hang onto them mentioned is also central to the argument of Simms (2004, p. 39) who sums this up as:

"In western and southern Germany there was no going back to the feudal status quo ante. The Prussian bureaucrats arriving in the newly acquired Rhine Province in 1815 found a population determined to hold onto the French law ... The genie of the reform movement-freedom of movement, the standardization of taxation, the abolition of guilds - could not be put back in the bottle."

Elsewhere, most notably in Hanover, there was much more of a return to the status quo. After 1815 the reforms implemented by the French persisted in precisely those areas where old elites were unable to return. Figure 4, from Acemoglu, Cantoni, Johnson and Robinson (2010), breaks down the urbanization rate within Germany, as a proxy for economic development, into three areas. Those that were never reformed by the French, those that were reformed but were given to Prussia in 1815, and those that were reformed but not given to Prussia and hence reverted to their pre-1792 elites. The Figure shows that after 1850 there is a distinct increase in the rate of growth of urbanization in all three regions but that it is significantly greater in the group which was reformed and given to Prussia. The growth in the reformed group taken 
over by Prussia comes from the persistence of reforms implemented by the French which the Prussians could not, or did not want to reverse. Indeed the Code Napoléon was in force in the Rhineland until 1900. It was in this part of Germany where new elites emerged and consolidated during the Revolutionary epoch. One sees that reform followed by the re-implantation of the old elites did not lead to any more rapid acceleration in urbanization compared to places which were unreformed since the old elites attempted to unwind the French reforms.

Thus to understand the impact of the reforms brought by the French during the revolutionary period it is crucial to understand how they impacted elites, their interests and their abilities to reverse and oppose change.

\section{Conclusions}

The institutions of a society which determine their development potential and prospects are deeply rooted in the histories of those societies. Once established, institutions persist for long periods of time. In this chapter I have argued that a key to understanding the persistence of institutions is the nature of elites: how elites form round sets of institutions and how elites reproduce and change over time. My argument implies that understanding why poor countries don't improve their institutions and how to encourage this process via policy necessitates the study of elites in the developing world. Incumbent elites often benefit, economically and politically, from the institutional status quo (recall my discussion of the Americo-Liberians). We need to study how elites arise, cohere and act to further their collective interests. We also need to understand much better how reforms influence existing and potential elite interests and strategies. 


\section{References}

Acemoglu, Daron, Davide Cantoni, Simon Johnson and James A. Robinson (2009) "The Consequences of Radical Reform: The French Revolution ," NBER Working Paper \#14831.

Acemoglu, Daron, Davide Cantoni, Simon Johnson and James A. Robinson (2010) "From Ancien Régime to Capitalism: The Spread of the French Revolution as a Natural Experiment," in Jared Diamond and James A. Robinson eds. Natural Experiments in History, Cambridge: Harvard University Press.

Acemoglu, Daron, Simon Johnson and James A. Robinson (2001) "The Colonial Origins of Comparative Development: An Empirical Investigation," American Economic Review, 91, 1369-1401.

Acemoglu, Daron, Simon Johnson and James A. Robinson (2002) "Reversal of Fortune: Geography and Institutions in the Making of the Modern World Income Distribution," Quarterly Journal of Economics, 118, 1231-1294.

Acemoglu, Daron, Simon Johnson and James A. Robinson (2005) "Institutions as a Fundamental Cause of Development," in Philippe Aghion and Steven Durlauf eds. The Handbook of Economic Growth, Amsterdam: North-Holland.

Acemoglu, Daron and James A. Robinson (2006) Economic Origins of Dictatorship and Democracy, New York: Cambridge University Press.

Acemoglu, Daron and James A. Robinson (2007) "A Model of the Iron Law of Oligarchy," Unpublished.

Acemoglu, Daron and James A. Robinson (2008a) "Persistence of Power, Elites and Institutions," American Economic Review, forthcoming March.

Acemoglu, Daron and James A. Robinson (2008b) "The Persistence and Change of Institutions in the Americas," Southern Economic Journal, 75, 282-99.

Acemoglu, Daron and James A. Robinson (2010) Why Nations Fail, forthcoming New York: Crown. 
Amsden, Alice H. (1989) Asia's next Giant: South Korea and Late Industrialization, New York: Oxford University Press.

Bateman, Fred and Thomas Weiss (1981) A deplorable scarcity: the failure of industrialization in the slave economy, Chapel Hill: University of North Carolina Press.

Bates, Robert H. (1981) Markets and States in Tropical Africa, Berkeley: University of California Press.

Besley, Timohty, Torsten Persson and Daniel Sturm (2010) "Political Competition, Policy and Growth: Theory and Evidence from the United States," Review of Economic Studies forthcoming.

Blanning, Timothy C.W. (1983) The French Revolution in Germany: Occupation and Resistance in the Rhineland, 1792-1802, New York: Oxford University Press.

Brenner, Robert (1976) "Agrarian Class Structure and Economic Development in Preindustrial Europe," Past and Present, 70, 30-75.

Casaús Arzú, Marta (2007) Guatemala: linaje y racismo, 3rd Edition, Guatemala: F\&G Editores.

Connelly, Owen (1965) Napoleon's Satellite Kingdoms, New York: Free Press.

Cooper, Frederick (2002) Africa since 1940: The Past of the Present, New York: Cambridge University Press.

Dalton, George (1964) "History, Politics and Economic Development in Liberia, Journal of Economic History, 25, 569-591.

Dell, Melissa (2007) "The Mineral Mita: Explaining Persistence of Institutions in Andean Peru," Unpublished, Department of Economics, MIT.

Diefendorf, Jeffry (1980) Businessmen and Politics in the Rhineland, 1789-1834, Princeton: Princeton University Press.

Evans, Peter B. (1995) Embedded Autonomy, Princeton: Princeton University Press.

Fraenkel, Merran (1964) Tribe and Class in Monrovia, New York: Oxford University Press. 
Haggard, Stephan (1990) Pathways from the Periphery: The Politics of Growth in the Newly Industrializing Countries, Ithaca: Cornell University Press.

Heinicke, Craig (1994) "African-American Migration and Mechanized Cotton Harvesting, 1950-1960," Explorations in Economic History, 31, 501-520.

Kisch, Herbert (1989) From Domestic Manufacture to Industrial Revolution: The case of the Rhineland Textile Districts, New York: Oxford University Press.

Mamdani, Mahmood (1996) Citizen and Subject, Princeton: Princeton University Press.

McAdam, Douglas (1983) "Tactical Innovation and the Pace of Insurgency," American Sociological Review, 48, 735-754.

Michels, Robert (1915) Political Parties: A sociological study of the oligarchical tendencies of modern democracies, London: Jarrold and Sons.

Mosca, Gaetano (1939) The ruling class, New York: McGraw-Hill.

North, Douglass C. (1990) Institutions, Institutional change, and Economic Performance, New York: Cambridge University Press.

North, Douglass C. and Robert P. Thomas (1973) The Rise of the Western World: A New Economic History, New York: Cambridge University Press.

Paige, Jeffrey M. (1997) Coffee and Power: Revolution and the Rise of Democracy in Central America, Cambridge: Harvard University Press.

Pareto, Vilfredo (1968) The rise and fall of the elites, New York: Arno Press.

Postan, Michael M. (1944) "The Rise of the Money Economy," Economic History Review, 14, 123-134.

Ransom, Roger L. and Richard Sutch (2001) One Kind of Freedom: the economic consequences of emancipation, 2nd Edition, New York: Cambridge University Press.

Simms, Brendan (2004) "Political and Diplomatic Movements, 1800-1830; Napoleon, national uprising, restoration" in Jonathan Sperber ed. The Shorter Oxford History of Germany: Germany 1800-1870, New York; Oxford University Press. 
Stone, Samuel Z. (1990) The heritage of the conquistadors: ruling classes in Central America from the Conquest to the Sandinistas, Lincoln: University of Nebraska Press.

Wade, Robert H. (1990) Governing the Market: Economic Theory and the Role of Government in East Asian Industrialization, Princeton: Princeton University Press.

Wiener, Jonathan M. (1978) Social Origins of the New South, Alabama, 1860-1885, Baton Rouge: Lousiana State University Press.

Woodward, C. Vann (1955) The Strange Career of Jim Crow, New York: Oxford University Press.

Wright, Gavin (1986) Old South, New South, New York: Basic Books.

Wright, Gavin (1999) "The Civil Rights Revolution as Economic History," Journal of Economic History, 59, 267-289.

Young, Crawford (1994) The African colonial state in comparative perspective, New Haven: Yale University Press. 
Figure 1: Social Relations and Political appointees of President Tubman in 1960

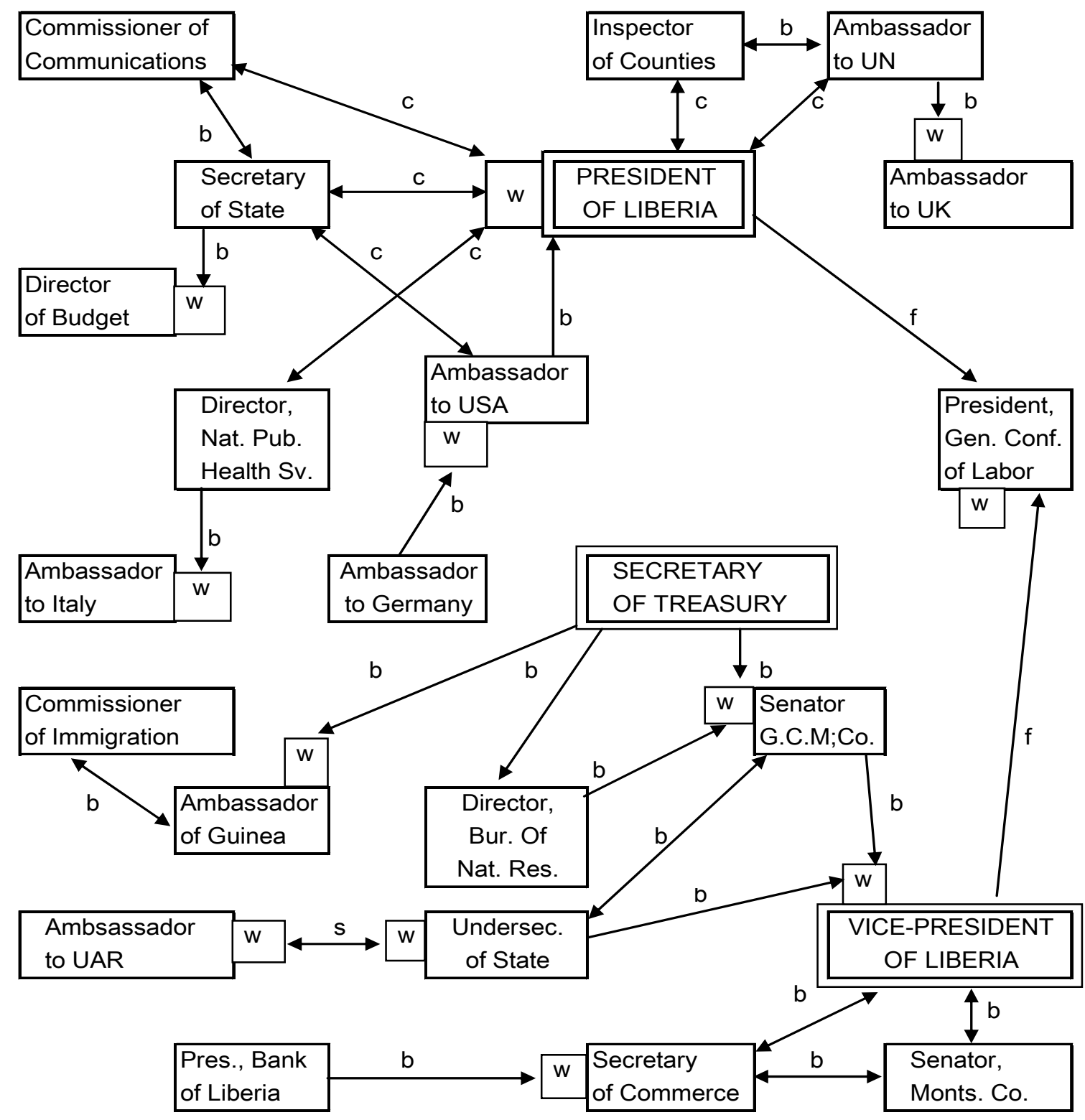

Key $: \mathrm{b}=$ brother; $\mathrm{f}=$ father $; \mathrm{c}=\operatorname{cousin} ; \mathrm{s}=$ sister; $\mathrm{w}=$ wife

Source: Clower et al. (1966, Chart 1, p. 13) 
Figure 2: Liberia: Constraints in the Executive and Polity Index

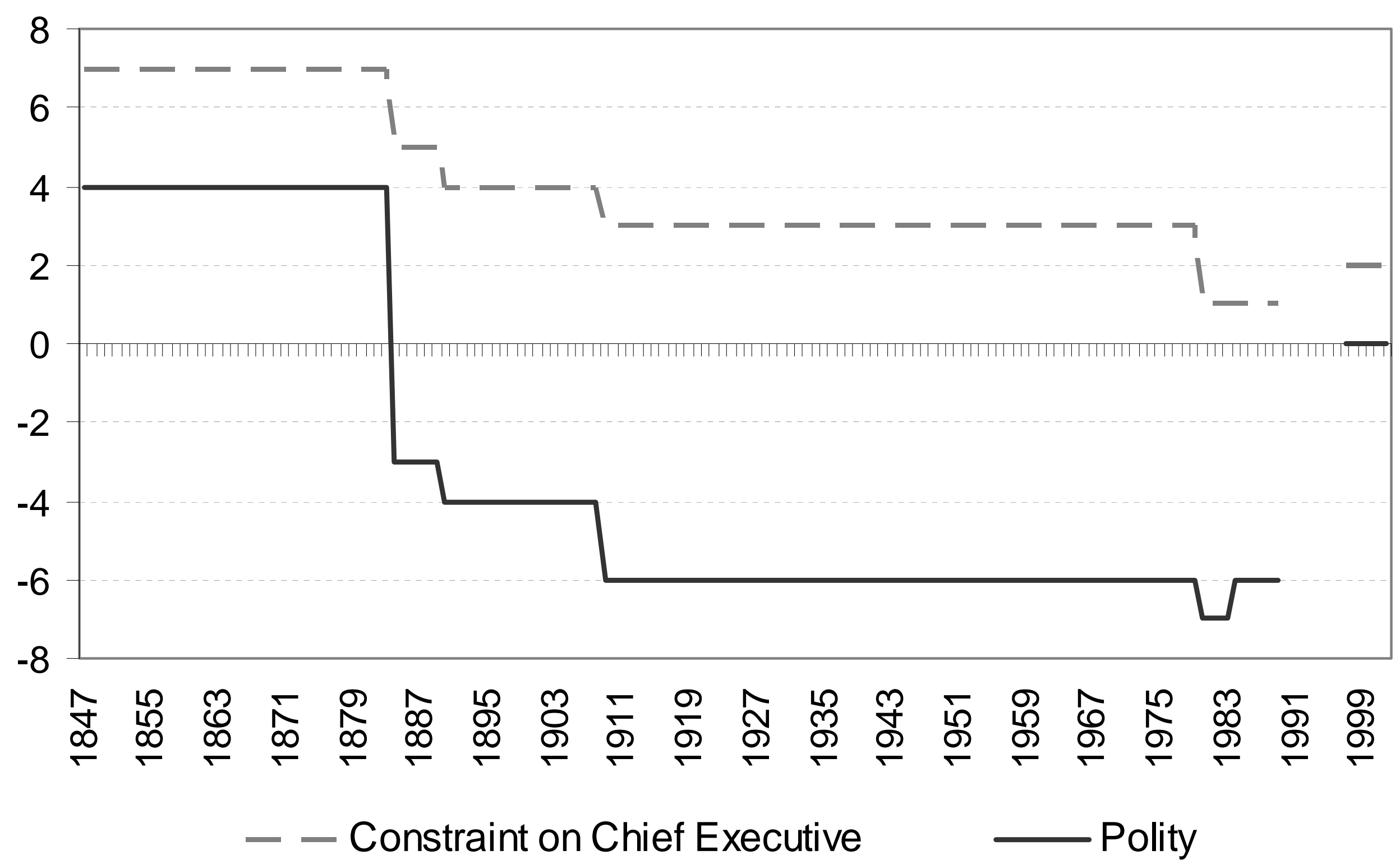


Table 1. The Persistence of the Landed Elite in Four "Black Belt" Counties of Alabama

\begin{tabular}{|c|c|c|c|c|}
\hline \multirow{3}{*}{ the } & (n) & \multirow{2}{*}{\multicolumn{3}{|c|}{ Real estate holdings ${ }^{a}$}} \\
\hline & & & & \\
\hline & & 1870 & 1860 & 1850 \\
\hline Name & County & (\$) & (\$) & $(\$)$ \\
\hline Minge, $G$. & Marengo & 85,000 & & 30,000 \\
\hline Lyon, F. & Marengo & 75,000 & 115,000 & 35,000 \\
\hline Paulling, William & Marengo & 72,000 & 150,000 & 29,000 \\
\hline Hatch, Alfred & Hale & 70,000 & 120,000 & 40,000 \\
\hline Alexander, J. & Marengo & 69,000 & 38,000 & $10,000^{\mathrm{b}}$ \\
\hline Whitfield, B. & Marengo & 65,000 & $200,000^{\mathrm{b}}$ & 100,000 \\
\hline Terrill, J. & Marengo & 62,000 & 93,000 & \\
\hline Taylor, E. & Marengo & 61,000 & & \\
\hline Robertson, R. & Marengo & 60,000 & & \\
\hline Dew, Duncan & Greene & 52,000 & $200,000^{\mathrm{b}}$ & 41,000 \\
\hline Walton, John & Marengo & 50,000 & 250,000 & 25,000 \\
\hline Collins, Charles & Hale & 50,000 & $201,000^{\mathrm{b}}$ & 30,000 \\
\hline Hays, Charles & Greene & 50,000 & 113,000 & \\
\hline Brown, John & Sumter & 50,000 & 69,000 & 13,000 \\
\hline Pickering, Richard & Marengo & 50,000 & 42,000 & 15,000 \\
\hline Withers, Mary & Hale & 50,000 & 40,000 & $75,000^{b}$ \\
\hline Jones, Madison & Hale & 50,000 & $36,000^{\mathrm{b}}$ & 27,000 \\
\hline Nelson, A. & Hale & 48,000 & & $10,000^{\mathrm{b}}$ \\
\hline Taylor, J. & Hale & 48,000 & & \\
\hline Pickens, Wm. & Hale & 45,000 & $210,000^{\mathrm{b}}$ & 51,000 \\
\hline Reese, Henry & Marengo & 45,000 & 52,000 & 24,000 \\
\hline Walker, R. & Hale & 42,000 & 55,000 & \\
\hline Smaw, W. & Greene & 42,000 & 32,000 & \\
\hline Blanks, E. & Marengo & 41,000 & & \\
\hline Walker, Morns & Marengo & 41,000 & & \\
\hline Number of planters & & 25 & 18 & 16 \\
\hline Percent present in 1870 & & & $72 \%$ & $64 \%$ \\
\hline \multicolumn{2}{|c|}{ Source: Wiener (1978, table 2, p. 12) } & & & \\
\hline \multicolumn{5}{|c|}{${ }^{2}$ Rounded off to the nearest thousand; as reported in the U.S. Census of Population, } \\
\hline \multicolumn{4}{|c|}{ manuscript schedules. To convert to constant gold prices, see p. 14, note 13 . } & \\
\hline bealth of father or husband & & & & \\
\hline
\end{tabular}




\title{
Table 2: CV of Max Sisulu
}

Mr. Sisulu was involved in the ANC since his youth, and went into exile in 1963, working in the liberation movement in Tanzania, Zambia and other parts of Africa. In 1986 he established the ANC's economics department, and returned to South Africa in 1993 taking a post in government. In 1994 he became a member of Parliament and in 1997 he was appointed Chief Whip in the National Assembly.

Education: MA in Political Economy at Piekhanov Institute, Moscow, Russia

Senior Military Commanders Course, Skhodnia, Russia

MA in Public Administration, JFK School of Govt., Harvard University

\section{Work Experience:}

\author{
South African National Assembly - Member of Parliament \\ National Institute of Economics Policy - Director \\ SA Aerospace, Maritime and Defense Industries Assoc. - Chairman \\ Human Science Research Council - Council Member \\ Free State's Economic Advisory Council - Advisor \\ ANC - National Executive Committee Member
}

\section{Directorships:}

Denel - Deputy CEO

African Rainbow Minerals - Non-Executive Director

ChemCity - Non-Executive Director

Harmony Gold Mining Company - Former Non-Executive Director

Imperial Holding - Non-Executive Board Member

Imperial/Ukhamba/Tata - Non-Executive Director

Manyano Communications - Director

Resolve Group - Non-Executive Board Member

Sasol - Executive General Manager

Stock Building Africa - Board Member

Tiyende telecommunications - Executive Director

Ukhamba Holdings - Non-Executive Chairman 


\section{Figure 3: ANC Politicians and BEE Companies by Sectors}

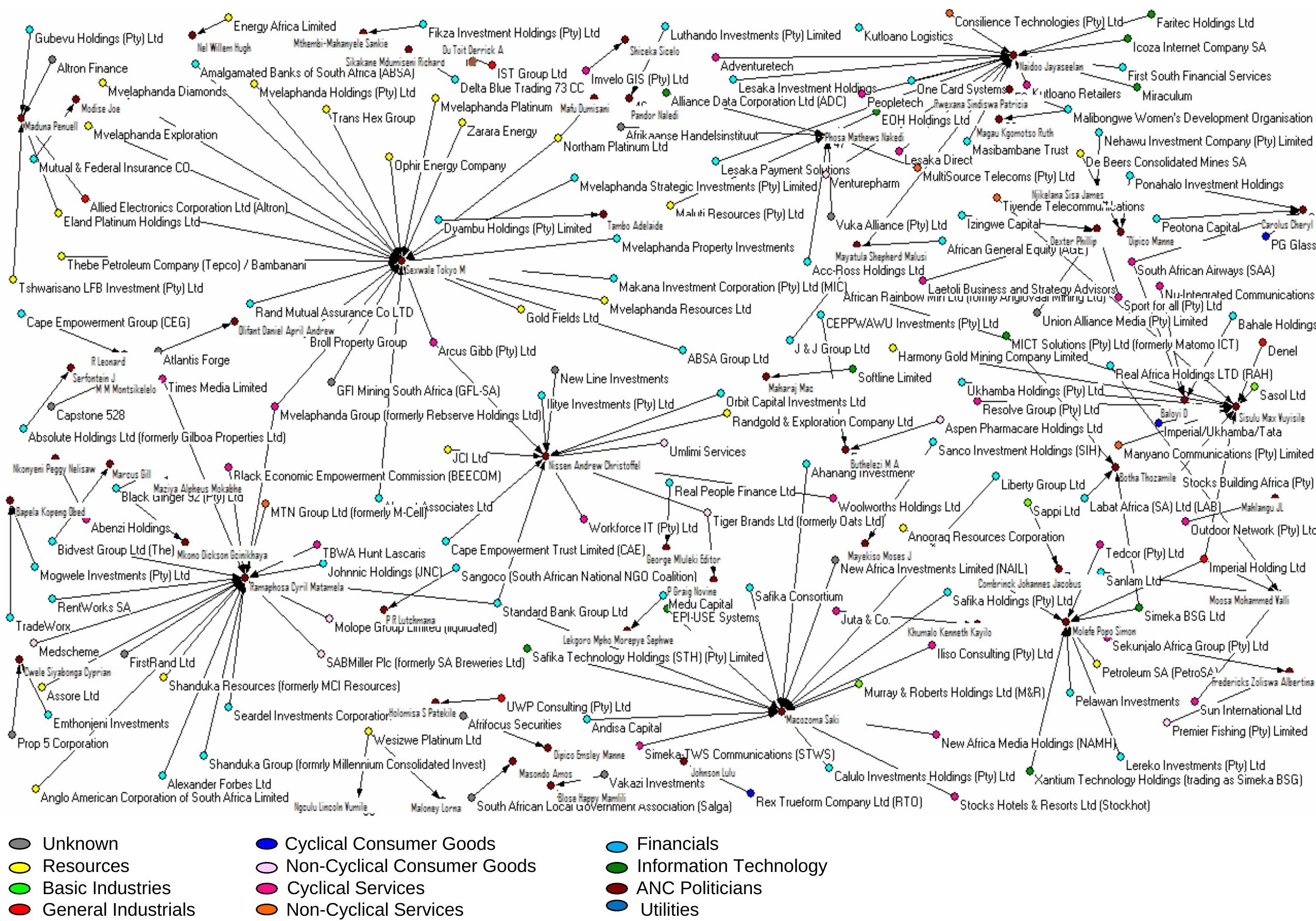


Figure 4: Urbanization by Region in Germany in the $19^{\text {th }}$ Century

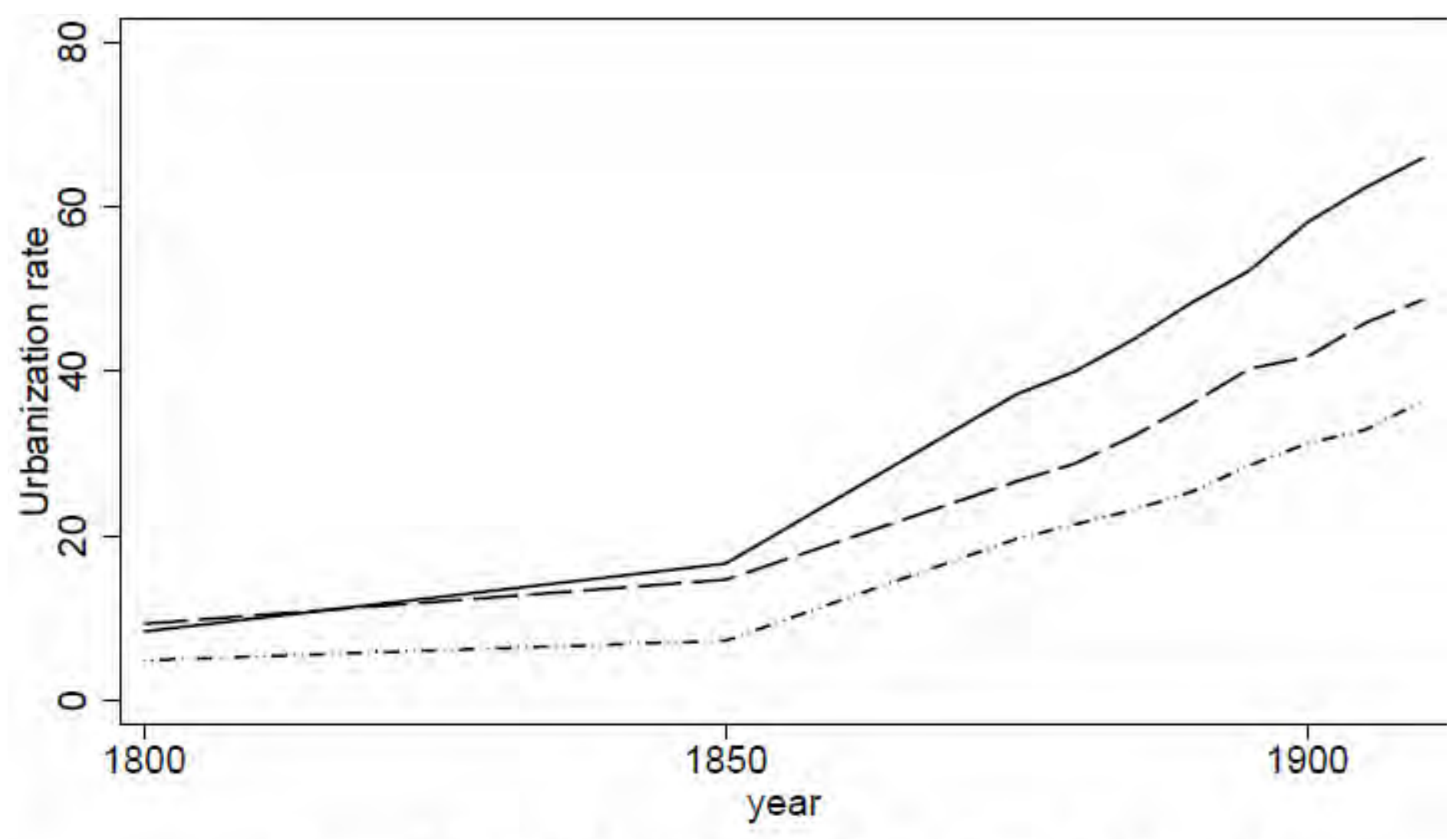

- Invaded, then Prussian $-\longrightarrow$ Not invaded

.........- Invaded, not to Prussia 